\title{
Inhibitory activity of crude bacteriocin produced by lactic acid bacteria isolated from dadih against Listeria monocytogenes
}

\author{
USMAN PATO ${ }^{1, \bullet}$, YUSMARINI YUSUF ${ }^{1}$, SHANTI FITRIANI ${ }^{1}$, NIA NAIDYA JONNADI ${ }^{1}$, \\ MIMI SRI WAHYUNI ${ }^{1}$, JESKA ARYANINGSIH FERUNI ${ }^{1}$, IRWANDI JASWIR ${ }^{2}$ \\ ${ }^{1}$ Department of Agricultural Technology, Faculty of Agriculture, Universitas Riau. Jl. H.R. Soebrantas Km. 12,5, Kampus Bina Widya, Simpang Baru, \\ Pekanbaru 28293, Riau, Indonesia. Tel.: +62-761-63270, Fax.: +62-761-63271, `email: usmanpato@yahoo.com \\ ${ }^{2}$ International Institute for Halal Research and Training, International Islamic University Malaysia. Jl. Gombak, Selangor, 53100, Malaysia
}

Manuscript received: 26 December 2019. Revision accepted: 4 March 2020.

\begin{abstract}
Pato U, Yusuf Y, Fitriani S, Jonnadi NN, Wahyuni MS, Feruni JA, Jaswir I. 2020. Inhibitory activity of crude bacteriocin produced by lactic acid bacteria isolated from dadih against Listeria monocytogenes. Biodiversitas 21: 1295-1302. The use of natural preservatives called bacteriocin derived from lactic acid bacteria (LAB) is one way of preventing food from being contaminated by pathogenic microorganisms such as Listeria monocytogenes (LM). The aims of this study were to evaluate the ability of LAB isolated from dadih to inhibit the growth of LM and to obtain the antimicrobial components that play a role in inhibiting the growth of LM. The antimicrobial activity of the supernatant obtained from 12 strains of dadih LAB was determined using the paper disk diffusion method. The results showed that the supernatant from the $12 \mathrm{LAB}$ strains was able to inhibit the growth of LM with various inhibition zones. However, out of the $12 \mathrm{LABs}$, only 9 strains were found to have an inhibition zone of more than $3.5 \mathrm{~mm}$. The antimicrobial compounds of 9 strains were tested and it was found that the antimicrobial compounds of strains R-8, R-14 and R-49 were derived from lactic acid. In addition, 6 strains namely R-43, R-32, R-19, R-55, R-45 and R-41 were derived from bacteriocin based on their sensitivity to pH, heat and enzyme treatments. Crude bacteriocin derived from 6 LAB strains inhibited the growth of LM, and the highest antimicrobial activity was obtained in Streptococcus faecalis subsp. liquefaciens R-55 with an average inhibition zone of $13.87 \mathrm{~mm}$. Bacteriocin produced by strain R-55 can be used as natural preservatives for the prevention of food-borne disease caused by LM.
\end{abstract}

Keywords: Antimicrobial activity, lactic acid bacteria, Listeria monocytogenes, bacteriocin, preservative compound

\section{INTRODUCTION}

Listeria monocytogenes (LM) is one of 9 species of Listeria that can cause listeriosis in humans. Listeriosis is a potentially fatal infection that is generally transmitted through food, results in a high rate of hospitalization (> $90 \%$ ) and death (20-30\%) in large outbreaks (Dussurget 2008; Hernandez-Milian 2014; McLauchin et al. 2004) There are two types of diseases associated with LM infections, namely non-invasive listeriosis which is a type of mild disease and invasive listeriosis which is a fatal and severe disease (FDA 2012). In most cases, the mild symptoms that are commonly observed include myalgia, headache, diarrhea and a fever (FAO/WHO 2004). The incidence rate of listeriosis is relatively rare, ranging from 1 to 10 cases per million per year. However, listeriosis has an important impact on public health considering that it is responsible for the highest rate of hospitalization and death among food-borne infections (Mead et al. 1999; Bille et al. 2006). The USA Centers for Disease Control and Prevention (CDC 2019) reported that 24 people were infected by LM and among them, 22 people were hospitalized and 2 people died.

LM is often associated with many animals (Leclercq 2015), therefore these pathogens can be found as contaminants in many raw food products derived from animals. They contaminate the resulting processed products during the processing mechanism itself. This is where the mechanisms involved do not apply the principles of good sanitation and hygiene. The United States Department of Agriculture and the Department of Food Safety and Inspection (USDA-FSIS) found an incidence of contamination of $7.24 \%$ in sausages cooked in 1991 and $7.69 \%$ in ham and lunch slices in 1996 (Levine et al. 2001), in addition to in sausage fermentation (Thevenot et al. 2005), end products (Gianfranceschi et al. 2006), dairy products especially cheese (Goulet et al. 2001; Makino et al. 2005), meat and fish products and fast food (McLauchin et al. 2004).

Some of the processed food products available in the market use various types of preservatives, generally chemical preservatives that can help the products to last longer without being contaminated by the pathogenic microbes that cause food-borne diseases. Chemical preservatives used commercially includes calcium propionate, sodium nitrate, sodium nitrite and sulfite compounds such as sulfur dioxide, sodium bisulfite, potassium hydrogen sulfite and disodium (US FDA 1993). The massive use of chemical preservatives by the food processing industry is due to the fact that these preservatives are easily obtained and widely traded in chemical stores. However, chemical preservatives are not always safe for human consumption because sometimes they can cause health problems ranging from allergies and asthma through to cancer (Anand and Sati 2013). Therefore it is necessary to look for safer natural food preservatives. 
Lactic acid bacteria (LAB) are known for their ability to produce various inhibitors including metabolic end products such as organic acids, hydrogen peroxide and bacteriocin (Rajaram et al. 2010; Sankar et al. 2012; Zhou et al. 2014). The direct application of LAB strains or their antimicrobial products in order to inhibit unwanted bacteria in food is introduced in the concept of biopreservation (Stiles 1996). Many recent studies and reviews have discussed this issue extensively (Cleveland et al. 2001; Deegan et al. 2006; Ross et al. 2002). LAB is the bacteria most often used in fermented foods because it has a long history of safe use. It is a microbe that lives in the digestive tract of both humans and animals (Maragkoudakis et al. 2009). L. salivarius isolated from chicken carcasses has the potential to be used as a preservative to increase safety and to extend the shelf life of chicken products (Sakaridis et al. 2014). Bacteriosinogenic LAB has been shown to inhibit the growth of pathogenic and spoilage bacteria in meat (Gálvez et al. 2008; Lücke 2000; Díaz-Ruiz et al. 2012), including in sausage fermentation (Leroy et al. 2006) and some food products (Bredholt et al. 1999; Buchanan and Bagi 1997; Dimitrijevic'et al. 1999; Duffes et al. 1999). Bacteriocin is an alternative bio preservative compound produced by LAB that can be used in food as having bactericidal properties against Gram-positive and Gramnegative bacteria. It is thus very beneficial for the food industry because of its activity of inhibiting the growth of the disease-carrying bacteria that are usually present in food. Bacteriocin has the potential to act as a natural preservative to replace chemical preservatives in food. Enterococcus, Lactobacillus, Pediococcus, Leuconostoc, and Carnobacterium are genera of LAB that commonly produce bacteriocin (Eijsink et al. 2002). Nisin is produced by Lactococcus lactis subsp. lactis has been used for commercial food preservation. Hosono et al. (1989) isolated 4 genera of LAB from dadih, a fermented food made from buffalo milk similar to yogurt, namely Lactobacillus sp., Streptococcus sp., Leuconostoc sp. and Lactococcus sp. Dadih's LAB has never been studied for their antimicrobial activity before even though these strains have an anti-mutagenic ability against various mutagen compounds (Hosono et al. 1990). The purposes of the present study were to evaluate the ability of BAL isolated from dadih to inhibit the growth of Listeria monocytogenes and to determine the type of antimicrobial compounds involved.

\section{MATERIALS AND METHODS}

\section{Study area}

The study was conducted in the Laboratory of Agricultural Product Analysis, Faculty of Agriculture, Universitas Pekanbaru, Riau, Indonesia $\left(0^{\circ} 25^{\prime}-0^{\circ} 45^{\prime} \mathrm{N}\right.$ and $101^{\circ} 14^{\prime}-101^{\circ} 34^{\prime} \mathrm{E}$ ). The map of study area is shown in Figure 1.

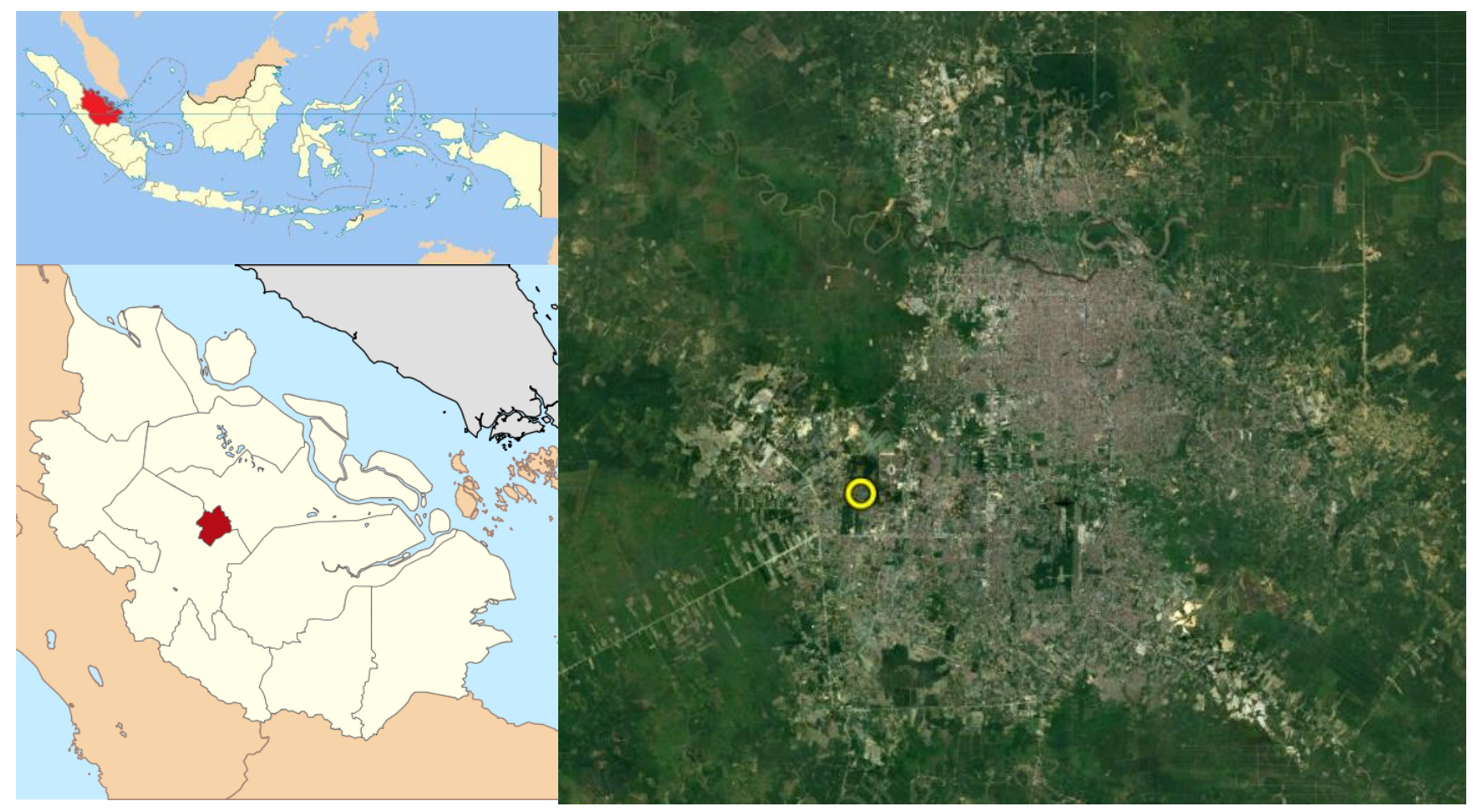

Figure 1. Study area in Universitas Riau (yellow circle), Pekanbaru, Riau Provinsi, Indonesia $\left(0^{\circ} 25^{\prime}-0^{\circ} 45^{\prime}\right.$ N and $101^{\circ} 14^{\prime}-101^{\circ} 34^{\prime}$ E) 


\section{Dadih's LAB and pathogenic bacteria}

In this study, 12 strains of LAB namely Leu. paramesenteroides $\mathrm{R}-8$, St. cremoris $\mathrm{R}-14$, St. faecalis subsp. liquefaciens R-19, St. lactis subsp. diacetylactis R22, Leu. paramesenteroides R-31, St. lactis subsp. diacetylactis R-41, St. lactis subsp. diacetylactis R-43, Leu. paramesenteroides R-45, Leu. paramesenteroides R-49, St. faecalis subsp. liquefaciens $\mathrm{R}-55$ and St. faecalis subsp. Liquefaciens R-56 isolated from dadih (Hosono et al. 1989) were screened for their antimicrobial activity. The pathogenic gram-positive bacterium used was Listeria monocytogenes FNCC-0156.

\section{Activation of the $\mathrm{LAB}$ culture and pathogenic bacteria}

The active culture was made by taking $0.1 \mathrm{~mL}$ of the dadih LAB culture in a test tube containing $5 \mathrm{~mL}$ of MRS broth. It was then shaken evenly and incubated at $37^{\circ} \mathrm{C}$ for 18 hours. The pathogenic bacteria was activated by inoculating $0.1 \mathrm{ml}$ of the test bacteria into $5 \mathrm{~mL}$ of the nutrient broth before it was shaken evenly and incubated at $37^{\circ} \mathrm{C}$ for 18 hours.

\section{Antimicrobial activity of the dadih LABs in the in-vitro test}

The antimicrobial activity of the supernatant obtained from the 12 strains of dadih $\mathrm{LAB}$ was determined using the paper disk diffusion method as described by Saranya and Hemashenpagam (2011) and Syukur et al. (2014). The cultures of dadih $\mathrm{LAB}$ were incubated aerobically at $37^{\circ} \mathrm{C}$ for 24 hours. The indicator bacterium, L. monocytogenes, was grown in nutrient broth at $37^{\circ} \mathrm{C}$ for 24 hours. Following this, $100 \mu \mathrm{L}$ of pathogenic microorganisms were placed and spread using glass hockey sticks on the surface of MRS agar. The sterile paper disc $(6 \mathrm{~mm})$ is dipped into the LAB supernatants and into sterile MRS broth as a negative control. The discs are then put onto the surface of MRS agar plates that have been previously seeded with the indicator bacteria. The plates were incubated at $37^{\circ} \mathrm{C}$ for 24 hours. After incubation, the diameter of the zone of growth inhibition was measured.

\section{Characterization of bacteriocin \\ Effect of $p H$}

In order to determine the effect of $\mathrm{pH}, 0.5 \mathrm{~mL}$ of purified bacteriocin was added to $4.5 \mathrm{~mL}$ of nutrient broth with different $\mathrm{pH}$ values ( 3 to 11 ) and incubated for $30 \mathrm{~min}$ at $37^{\circ} \mathrm{C}$. Each of the bacteriocin samples treated at different $\mathrm{pH}$ values was assayed against the indicator bacteria through the agar diffusion method (Saranya and Hemashenpagam 2011; Syukur et al. 2014).

\section{Effect of temperature}

Purified bacteriocin $(0.5 \mathrm{~mL})$ was added to $4.5 \mathrm{ml}$ of nutrient broth in the test tube. Each test tube was then overlaid with paraffin oil to prevent evaporation before being heated at different temperatures $(30,40,50,60,70$, $80,90,100$ and $121^{\circ} \mathrm{C}$ ) for 10 minutes. The preparations containing nutrient broth $(4.5 \mathrm{~mL})$ and bacteriocin $(0.5 \mathrm{~mL})$ were plugged with non-absorbent cotton, covered with aluminum foil and kept in an autoclave at $121^{\circ} \mathrm{C}$ for 10 minutes to check its activity at very high autoclaving temperature. The bacteriocin activity of the above different heat-treated specimens was measured using the agar diffusion method (Saranya and Hemashenpagam 2013; Syukur et al. 2014).

\section{Effect of amylase and proteolytic enzymes}

The effect of amylase and proteolytic enzymes on the activity of crude bacteriocin was studied as described by Zhou et al. (2014). Crude bacteriocin was treated with amylase $(5 \mathrm{mg} / \mathrm{mL})$, trypsin $(5 \mathrm{mg} / \mathrm{mL})$, and proteinase $(5$ $\mathrm{mg} / \mathrm{mL})$ respectively and a phosphate buffer $(0.5 \mathrm{M}, \mathrm{pH}$ 7.0) was used as a control. The effect of the enzymes on bacteriocin activity was studied through the agar diffusion method (Saranya and Hemashenpagam 2013; Syukur et al. 2014) using the above preparations against LM as the indicator bacteria.

\section{Production of crude bacteriocin}

Dadih LABs were propagated in MRS broth $(1000 \mathrm{~mL})$ seeded with a $10 \%$ inoculum of overnight culture before being incubated at $37^{\circ} \mathrm{C}$ for 24 hours. After incubation, the whole broth was centrifuged at $10,000 \times \mathrm{g}$ for 15 minutes before the cell-free supernatant was collected. The cell-free culture supernatant was saturated with $70 \%$ ammonium sulfate and stored at $4^{\circ} \mathrm{C}$ to precipitate the proteins out. The crude bacteriocin was collected after centrifugation at $10,000 \mathrm{rpm}$ at $4^{\circ} \mathrm{C}$ for 30 minutes (Ogunbanwo et al. 2003; Sankar et al. 2012).

\section{RESULTS AND DISCUSSION}

In the present study, 12 lactic acid bacteria strains from the genus of Streptococcus sp. and Leuconostoc sp. isolated from dadih were evaluated for their antimicrobial activity against Listeria monocytogenes (Table 1). The inhibition zone produced by the cell-free supernatant indicated the secretion of the antibacterial compounds into the extracellular environment. St. lactis subsp. diacetylactis R43, Leu. paramesenteroides R-45 and St. faecalis subsp. liquefaciens $\mathrm{R}-19$ have the highest antimicrobial properties, while Leu. paramesenteroides R-8, St. cremoris R-14 and Leu. paramesenteroides $\mathrm{R}-31$ have the lowest antimicrobial activity.

The last three BAL strains were therefore not used in the next test. Some researchers have previously reported on the ability of LABs such as Enterococcus faecium, Pediococcus pentosaceus, and Lactococcuslactis subsp. lactis to inhibit the growth of L. monocytogenes (Pinto et al. 2009; Cosentino et al. 2012; Barman et al. 2014). Because of Leu. paramesenteroides R-8, St. cremoris R-14 and Leu. paramesenteroides R-31 have the lowest antimicrobial activity, these three BAL strains were not used in the next test.

To find out the antimicrobial compounds of the 9 dadih LABs, the testing was continued to evaluate the supernatant's sensitivity to various $\mathrm{pH}$ treatments. The results are as shown in Table 2. 
Table 2. Sensitivity of antimicrobial activity of supernatant from dadih's lactic acid bacteria against Listeria monocytogenes at various $\mathrm{pH}$

\begin{tabular}{|c|c|c|c|c|c|c|}
\hline \multirow{3}{*}{ Dadih's LAB } & \multicolumn{6}{|c|}{ Inhibition zone (mm) } \\
\hline & \multicolumn{6}{|c|}{$\mathbf{p H}$} \\
\hline & Control & 3 & 5 & 7 & 9 & 11 \\
\hline St. faecalis subsp. liquefaciens R-19 & 10.30 & 10.03 & 13.95 & 8.20 & 7.87 & 10.30 \\
\hline St. lactis subsp. diacetylactis $\mathrm{R}-22$ & 1.90 & 2.20 & 1.53 & $0.00 *$ & $0.00 *$ & $0.00 *$ \\
\hline St. faecalis subsp. liquefaciens $\mathrm{R}-32$ & 10.40 & 9.60 & 13.60 & 9.00 & 10.33 & 12.30 \\
\hline St. lactis subsp. diacetylactis $\mathrm{R}-41$ & 5.10 & 4.07 & 4.63 & 7.10 & 7.53 & 8.07 \\
\hline St. lactis subsp. diacetylactis $\mathrm{R}-43$ & 6.17 & 3.67 & 5.17 & 7.10 & 9.20 & 9.40 \\
\hline Leu. paramesenteroides $\mathrm{R}-45$ & 5.65 & 4.85 & 5.50 & 4.63 & 4.10 & 4.86 \\
\hline Leu. paramesenteroides R-49 & 2.43 & 1.30 & 0.43 & $0.00 *$ & $0.00 *$ & $0.00 *$ \\
\hline St. faecalis subsp. liquefaciens R-55 & 5.10 & 5.77 & 3.45 & 9.10 & 6.77 & 1.30 \\
\hline St. faecalis subsp. liquefaciens $\mathrm{R}-56$ & 2.43 & 3.00 & 2.77 & $0.00 *$ & $0.00 *$ & $0.00 *$ \\
\hline
\end{tabular}

Note: *Lost antimicrobial activity

Table 1. Antimicrobial activity of cell-free supernatant from dadih's lactic acid bacteria against Listeria monocytogenes

\begin{tabular}{lc}
\hline Dadih's LAB & $\begin{array}{c}\text { Inhibition } \\
\text { zone }(\mathbf{m m})\end{array}$ \\
\hline Leu. paramesenteroides R-8 & 2.10 \\
St. cremoris $\mathrm{R}-14$ & 1.60 \\
St. faecalis subsp. liquefaciens $\mathrm{R}-19$ & 5.40 \\
St. lactis subsp. diacetylactis $\mathrm{R}-22$ & 8.10 \\
Leu. paramesenteroides $\mathrm{R}-31$ & 2.80 \\
St. faecalis subsp. liquefaciens $\mathrm{R}-32$ & 3.30 \\
St. lactis subsp. diacetylactis $\mathrm{R}-41$ & 3.83 \\
St. lactis subsp. diacetylactis $\mathrm{R}-43$ & 6.20 \\
Leu. paramesenteroides $\mathrm{R}-45$ & 5.97 \\
Leu. paramesenteroides $\mathrm{R}-49$ & 3.63 \\
St. faecalis subsp. liquefaciens $\mathrm{R}-55$ & 5.07 \\
St. faecalis subsp. liquefaciens $\mathrm{R}-56$ & 4.30 \\
\hline
\end{tabular}

Different kinds of antimicrobial compounds from LAB are derived from organic acids, diacetyl, hydrogen peroxide and proteinaceous bacteriocins (Daeschel 1989; Saranya and Hemashenpagam 2013). St. lactis subsp. diacetylactis R-22, Leu. paramesenteroides R-49 and St. faecalis subsp. liquefaciens R-56 lost their antimicrobial activity after the supernatants $\mathrm{pH}$ was set to 7 through to 11 . This indicates that the antimicrobial compounds from these three LABs are derived from organic acids, especially the lactic acid produced during their growth (Table 2). Similar results were reported by Pato et al. (2017) for Lb. casei subsp. casei R-68 isolated from dadih, Shokryazdan et al. (2014) for the L. casei Shirota, L. casei BF strain and $L$. acidophilus, L. fermentum, Neal-McKinney et al. (2012) for Lactobacilli, Keersmaecker et al. (2006) for $L$. rhamnosus, and GG, Vătuiu and Popa (2015) for $L$. delbrueckii. subsp. bulgaricus and Lac. lactis to inhibit various pathogens including Listeria monocytogenes by organic acids. The antimicrobial components of the other 6 dadih LAB strains, namely St. faecalis subsp. liquefaciens R-19, St. faecalis subsp. liquefaciens R-32, St. lactis subsp. diacetylactis R-43, Leu. paramesenteroides R-45, Leu. paramesenteroides R-49 and St. faecalis subsp. liquefaciens $\mathrm{R}-55$, are most likely proteinous bacteriocin.

This is characterized by no loss in the inhibitory zones even though the $\mathrm{pH}$ of the supernatant is adjusted to $\mathrm{pH} 11$ (Figure 2). Generally speaking, bacteriocin is a peptide or protein compound that is resistant to high heat as shown in Table 3. The antimicrobial potential of heat-killed supernatant supports the thermostable nature of the antimicrobial compound(s).

The data in Table 3 shows that the compounds that are likely to be bacteriocin presented in the supernatant were very resistant to temperatures up to $121^{\circ} \mathrm{C}$. Because the supernatants of the 6 dadih LABs were shown to have antimicrobial activity that was resistant to various heating temperatures and $\mathrm{pH}$, the study continued to isolate the crude bacteriocin from the LABs.

The antimicrobial activity of the crude bacteriocin against Listeria monocytogenes has been presented in Table 4. The crude bacteriocin from the 6 dadih LABs was able to inhibit the growth of Listeria monocytogenes with different inhibition zones.

The highest antimicrobial activity was obtained in St.faecalis subsp. liquefaciens R-55 and St.lactis subsp. diacetylactis $\mathrm{R}-41$. $\mathrm{T}$ lowest activity was found in St.faecalis subsp. liquefaciens R-32. The inhibition of Listeria monocytogens using bacteriocin-producing LAB strains has been reported by several researchers. P.acidilactici and Lac.lactis subsp. lactis MM217 produce bacteriocin that can inhibit the growth of Listeria monocytogenes in some dairy products (Pucci et al. 1988), cheddar cheese (Buyong et al. 1998), ready-to-eat meat products (Amezquita and Brashears 2002) and meat sausage model systems (Díaz-Ruiz et al. 2012).

Furthermore, the crude bacteriocin was evaluated for its sensitivity at various heating temperatures related to the growth of Listeria monocytogenes and the results have been presented in Table 5. 


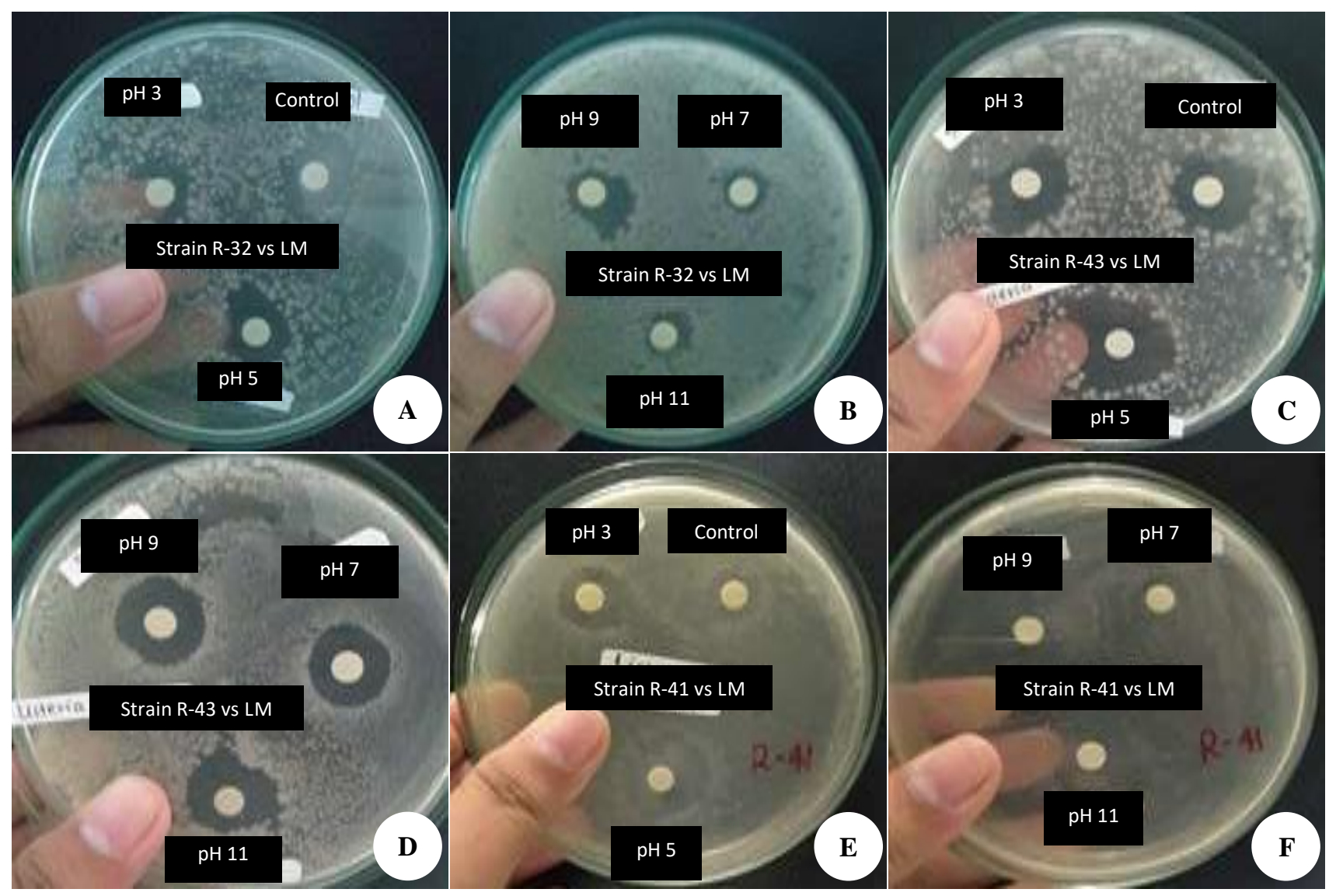

Figure 2. Antimicrobial activity of supernatants for some dadih's lactic acid bacteria against Listeria monocytogenes. A. Strain R-32 vs LM, B. Strain R-32 vs LM, C. Strain R-43 vs LM, D. Strain R-43 vs LM, E. Strain R-41 vs LM, F. Strain R-41 vs LM. Control = supernatant without $\mathrm{pH}$ adjustment, $\mathrm{pH} 3=$ supernatant adjusted to $\mathrm{pH} 3, \mathrm{pH} 7=$ supernatant adjusted to $\mathrm{pH} 7, \mathrm{pH} 9=$ supernatant adjusted to $\mathrm{pH} 9, \mathrm{pH} 11$ = supernatant adjusted to $\mathrm{pH} 11$ 
Table 3. Sensitivity of antimicrobial activity of supernatant from dadih's lactic acid bacteria against Listeria monocytogenes at various heat temperatures

\begin{tabular}{|c|c|c|c|c|c|c|c|}
\hline \multirow{3}{*}{ Dadih's LAB } & & \multicolumn{6}{|c|}{ Inhibition zone (mm) } \\
\hline & \multirow[b]{2}{*}{ Control } & \multicolumn{6}{|c|}{ Heat temperatures $\left({ }^{\circ} \mathrm{C}\right)$} \\
\hline & & 30 & 50 & 70 & 90 & 100 & 121 \\
\hline St. faecalis subsp. liquefaciens $\mathrm{R}-19$ & 8.90 & 11.77 & 9.77 & 5.10 & 6.77 & 6.77 & 4.20 \\
\hline St. faecalis subsp. liquefaciens $\mathrm{R}-32$ & 9.47 & 8.10 & 8.97 & 12.23 & 8.87 & 7.97 & 5.33 \\
\hline St. lactis subsp. diacetylactis $\mathrm{R}-41$ & 6.30 & 7.23 & 7.10 & 9.33 & 8.67 & 7.10 & 4.10 \\
\hline St. lactis subsp. diacetylactis $\mathrm{R}-43$ & 8.33 & 7.43 & 8.90 & 5.47 & 6.10 & 6.57 & 3.10 \\
\hline Leu. paramesenteroides $\mathrm{R}-45$ & 8.20 & 9.23 & 9.33 & 6.00 & 8.00 & 7.00 & 3.47 \\
\hline St. faecalis subsp. liquefaciens $\mathrm{R}-55$ & 6.67 & 5.85 & 6.00 & 10.53 & 8.00 & 8.67 & 5.00 \\
\hline
\end{tabular}

Table 5. Sensitivity of antimicrobial activity of crude bacteriocin from dadih's lactic acid bacteria against Listeria monocytogenes at various heat temperatures

\begin{tabular}{|c|c|c|c|c|c|c|c|}
\hline \multirow{3}{*}{ Dadih's LAB } & & \multicolumn{6}{|c|}{ Inhibition zone (mm) } \\
\hline & \multirow[b]{2}{*}{ Control } & \multicolumn{6}{|c|}{ Heat temperatures $\left({ }^{\circ} \mathrm{C}\right)$} \\
\hline & & 30 & 50 & 70 & 90 & 100 & 121 \\
\hline St. faecalis subsp. liquefaciens $\mathrm{R}-19$ & 4.01 & 3.22 & 4.67 & 9.22 & 6.55 & 5.12 & 3.21 \\
\hline St. faecalis subsp. liquefaciens R-32 & 4.75 & 4.77 & 3.33 & 5.77 & 8.21 & 5.11 & 1.10 \\
\hline St. lactis subsp. diacetylactis R-41 & 5.99 & 10.87 & 6.2 & 5.43 & 4.63 & 4.43 & 1.30 \\
\hline St. lactis subsp. diacetylactis $\mathrm{R}-43$ & 5.66 & 4.76 & 5.86 & 4.88 & 3.99 & 4.88 & 3.30 \\
\hline Leu. paramesenteroides $\mathrm{R}-45$ & 5.32 & 7.32 & 5.77 & 4.67 & 4.99 & 4.67 & 1.50 \\
\hline St. faecalis subsp. liquefaciens $\mathrm{R}-55$ & 8.67 & 6.63 & 7.09 & 7.43 & 5.99 & 6.55 & 1.22 \\
\hline
\end{tabular}

Table 6. Antimicrobial activity of crude bacteriocin from dadih's lactic acid bacteria against Listeria monocytogenes treated with various enzymes

\begin{tabular}{lcccc}
\hline \multicolumn{1}{c}{ Dadih's LAB } & \multicolumn{2}{c}{ Inhibition zone (mm) } \\
\cline { 2 - 5 } & Control & Amylase & Trypsin & Proteinase K \\
\hline St. faecalis subsp. liquefaciens R-19 & 8.97 & 10.36 & 0.0 & 0.0 \\
St. faecalis subsp. liquefaciens R-32 & 6.45 & 11.23 & 0.0 & 0.0 \\
St. lactis subsp. diacetylactis R-41 & 5.09 & 13.80 & 0.0 & 0.0 \\
Leu. paramesenteroides R-43 & 6.76 & 15.76 & 0.0 & 0.0 \\
Leu. paramesenteroides R-45 & 5.99 & 10.33 & 0.0 & 0.0 \\
St. faecalis subsp. liquefaciens R-55 & 7.43 & 11.23 & 0.0 & 0.0 \\
\hline
\end{tabular}

Note: *Lost antimicrobial activity

Table 4. Antimicrobial activity of crude bacteriocin from dadih's lactic acid bacteria against Listeria monocytogenes

\begin{tabular}{lc}
\hline Dadih's LAB & $\begin{array}{c}\text { Inhibition zone } \\
(\mathbf{m m})\end{array}$ \\
\hline St. faecalis subsp. liquefaciens $\mathrm{R}-19$ & 5.57 \\
St. faecalis subsp. liquefaciens $\mathrm{R}-32$ & 5.00 \\
St. lactis subsp. diacetylactis $\mathrm{R}-41$ & 13.57 \\
St. lactis subsp. diacetylactis $\mathrm{R}-43$ & 6.10 \\
Leu. paramesenteroides $\mathrm{R}-45$ & 9.32 \\
St. faecalis subsp. liquefaciens $\mathrm{R}-55$ & 13.87 \\
\hline
\end{tabular}

The antimicrobial activity of crude bacteriocin was relatively resistant to temperatures up to $121^{\circ} \mathrm{C}$. These results confirm the resistance of the bacteriocin present in supernatants (Table 3) heated to the same temperature. To ensure that the antimicrobial component was bacteriocin, the sensitivity was tested using various enzymes, and the results have been presented in Table 6 .

The antimicrobial activity was not lost after the treatment with amylase, indicating that the antimicrobial component is not starch but protein. The loss of antibacterial activity after treatment with proteolitic enzymes such as trypsin and proteinase $\mathrm{K}$ demonstrates the proteinaceous nature of the antibacterial metabolite(s). It has already been reported by several researchers that the bacteriocin produced by lactic acid bacteria is a highly thermostable proteinaceous compound that shows antimicrobial activity even after autoclaving at $121^{\circ} \mathrm{C}$ (Mandal et al. 2013). Bacteriocin is protein compound that is biologically active when it comes to inhibiting bacterial growth in a group of related bacteria (Deraz et al. 2005). Most bacteriocins of LAB are peptide compounds with 
small molecular weights $(<10 \mathrm{kDa})$, in addition to being heat-resistant, cationic and amphiphilic (Saeed et al. 2014; Zacharof and Lovitt 2012).

In conclusion, all $12 \mathrm{LABs}$ isolated from dadih can inhibit the growth of Listeria monocytogenes. However, 9 strains were found to have an inhibition zone of more than $3.5 \mathrm{~mm}$. The antimicrobial compound of strains R-8, R-14, and R-49 derived from organic acids (mainly lactic acid) and the other 6 strains, namely R-19, R-32, R-41, R-43, R45 and R-55 derived from bacteriocin, was based on their sensitivity to $\mathrm{pH}$, enzymes and heat treatments. Crude bacteriocin derived from 6 LAB strains inhibited the growth of Listeria monocytogenes, and the highest antimicrobial activity was found in St. faecalis subsp. liquefaciens R-55.

\section{ACKNOWLEDGEMENTS}

We would like to thank the Directorate of Research and Community Service in the Ministry for Research, Technology and Higher Education of the Republic of Indonesia for the research grant.

\section{REFERENCES}

Anand SP, Sati N. 2013. Artificial preservatives and their harmful effects: Looking toward nature for safer alternatives. Intl J Pharm Sci Res 4 (7): 2496-2501.

Amézquita A, and Brashears MM. 2002. Competitive inhibition of Listeria monocytogenes in ready-to-eat meat products by lactic acid bacteria. J Food Prot 65: 316-325.

Barman S, Ghosh R, Mandal NC. 2014. Use of bacteriocin producing Lactococcus lactis subsp. lactis LABW4 to prevent Listeria monocytogenes induced spoilage of meat. Food Nutr Sci 5: 21152123.

Bille J, Blanc DS, Schmid H, et al. 2006. Outbreak of human Listeriosis associated with tome cheese in Northwest Switzerland 2005. Euro Surv 11 (6): 91-93

Bredholt S, Nesbakken T, Holck A. 1999. Protective cultures inhibit growth of Listeria monocytogenes and Escherichia coli O157: $\mathrm{H} 7$ in cooked, sliced, vacuum- and gas-packaged meat. Intl J Food Microbiol 53: 43-52.

Buchanan RL, Bagi LK. 1997. Microbial competition: Effect of culture conditions on the suppression of Listeria monocytogenes. Food Microbiol 16 (5): 798-703.

Buyong N, Kok J, Luchansky JB. 1998. Use of a genetically enhanced, Pediocin-producing starter culture, Lactococcus lactis subsp. lactis MM217, to control Listeria monocytogenes in cheddar cheese. Appl Environ Microbiol 64: 4842-4845.

Centers for Disease Control and Prevention (CDC). 2008. Outbreak of Listeria monocytogenes infections associated with pasteurized milk from a local dairy-Massachusetts, 2007. Morbidity and Mortality Weekly Report 57 (40): 1097-1100.

Centers for Disease Control and Prevention (CDC). 2019. Outbreak of Listeria Infections. Latest Outbreak Information. https:// www.cdc.gov/listeria/outbreaks/monocytogenes-08-19/index.html. [24 September 2019].

Cleveland J, Montville TJ, Nes IF, Chikindas ML. 2001. Bacteriocins: safe, natural antimicrobials for food preservation. Intl $\mathrm{J}$ Food Microbiol 71: 1-20

Cosentino S, Fadda ME, Deplano M, Melis R, Pomata R, Pisano MB. 2012. Antilisterial activity of nisin-like bacteriocin-producing Lactococcus lactis subsp. lactis isolated from traditional Sardinian dairy products. J Biomed Biotechnol 2012: 1-8.

Daeschel MA. 1989. Antimicrobial Substances from Acid Lactic Bacteria for Use as Food Preservative. Food Technol 43: 164-167.
Deegan LH, Cotter PD, Hill C, Ross P. 2006. Bacteriocins: biological tools for bio-preservation and shelf-life extension. Intl Dairy J 16 : 1058-1071.

Deraz SF, Karlsson EN, Hedstrom M, et al. 2005. Purification and characterisation of acidocin D20079, a bacteriocin produced by Lactobacillus acidophilus DSM 20079. J Biotechnol 117 (4): 343-54.

Díaz-Ruiz G, Omar NB, Abriouel H, Cañamero MM, Gálvez A. 2012. Inhibition of Listeria monocytogenes and Escherichia coli by bacteriocin-producing Lactobacillus plantarum EC52 in a meat sausage model system. J Microbiol Res 6 (6): 1103-1108.

Dimitrijevic' M, Teodorovic' V, Baltic' M, Mirlovic 'M. 1999. Variations in the sensitivity of Listeria monocytogenes types to lactic acid bacteria bacteriocins. Acta Vet (Belgr) 49: 49-56.

Duffes F, Leroi F, Boyaval P, Dousset X. 1999. Inhibition of Listeria monocytogenes by Carnobacterium spp. strains in a simulated coldsmoked system stored at $48^{\circ} \mathrm{C}$. Intl J Food Microbiol 47: 33-42.

Dussurget O. 2008. New insights into determinants of Listeria monocytogenes virulence. Intl Rev Cell Mol Biol 270: 1-38.

Eijsink VGH, Axelsson L, Diep DB, Havarstein LS, Holo H, Nes IF. 2002. Production of class II bacteriocins by lactic acid bacteria; an example of biological warfare and communication. Antonie Van Leeuwenhoek 8: 639-654.

FDA. 2012. Bad bug book: Foodborne pathogenic microorganisms and natural toxins handbook, 2nd ed. US Food and Drug Administration, Silver Spring. 100-104.

Gálvez A, López LR, Abriouel H, Valdivia E, Omar BN. 2008. Application of bacteriocins in the control of foodborne pathogenic and spoilage bacteria. Crit Rev Biotechnol 28: 125-152.

Gianfranceschi M, Gattuso A, Fiore A, D’Ottavio MC, Casale M, Palumbo A, Aureli P. 2006. Survival of Listeria monocytogenes in uncooked Italian dry sausage (salami). J Food Prot 69: 1533-1538.

Goulet V, De Valk H, Pierre O, Stainer F, Roccourt J, Vaillant V. 2001. Effect of prevention measures on incidence of human listeriosis, France, 1987-1997. Emerg Infect Dis 7: 983-989.

Hernandez-Milian A, Payeras-Cifre A. 2014. What Is new in listeriosis? Bio Med Res Intl 358051

Hosono A, Wardojo R, Otani H. 1989. Microbial flora in "dadih", a traditional fermented milk in Indonesia. Lebens-Wissen und-Technol 22: $20-24$.

Hosono A, Tanabe T, Otani H. 1990. Binding properties of lactic acid bacteria isolated from kefir milk with mutagenic amino acid pyrolysates. Milchwissenschaft. 45: 647-651.

Keersmaecker De SCJ, Verhoeven TLA, Desair J, Marchal K, Vanderleyden J, Nagy I. 2006. Strong antimicrobial activity of Lactobacillus rhamnosus GG against Salmonella typhimurium is due to accumulation of lactic acid. FEMS Microbiol Lett 259: 89-96.

Leclercq A. 2015. Chapter 2.9.7, Listeria Monocytogenes, 2015th ed. The World Organisation for Animal Health (OIE): Paris, France, 2015:1 18

Leroy F, Verluyten J, De Vuyst L. 2006. Functional meat starter cultures for improved sausage fermentation. Intl J Food Microbiol 106: 270285.

Levine P, Rose B, Green S, Ransom G, Hill W.2001. Pathogen testing of ready-to-eat meat and poultry products collected at federally inspected establishments in the United States, 1990 to 1999. J Food Prot 64: 1188-1193.

Lücke FK. 2000. Utilization of microbes to process and preserve meat. Meat Sci 56: 105-115.

Makino SI, Kawamato K, Takeshi K, Okada Y. Yamasaki M, Yamamoto S, Igimi S. 2005. An outbreak of food-borne listeriosis due to cheese in Japan, during 2001. Intl J Food Microbiol 104: 189-196.

Mandal V, Sen SK, Mandal NC. 2013. Production and Partial Characterization of an Inducer Dependent Novel Antifungal Compound(s) by Pediococcus acidilactici LAB5. J Sci Food Agric 93: 2445-2453.

Maragkoudakis PE, Mountzouris KC, Psyrras D, Cremonese S, Fischer J, Cantor MD, Tsakalidou E. 2009. Functional properties of novel protective lactic acid bacteria and application in raw chicken meat against Listeria monocytogenes and Salmonella enteritidis. Intl J Food Microbiol 130: 219-226.

McLauchin J, Mitchell RT, Smerdon WJ, Jewell K, Listeria monocytogenes and related specie. 2004. Listeria monocytogenes and listeriosis: A Bergant, T., Norris, J. (Eds), Methods in review of hazard characterization for use in Microbiology. Academic Press, New York, pp: 33-microbiological risk assessment of foods. Intl J Food Microbiol 92: 15-33. 
Mead PS, Slutsker L, Dietz V, et al. 1999. Food-related illness and death in the United States. Emerg Infect Dis 5 (5): 607-625.

Neal-McKinney JM, Lu X, Duong T. 2012. Production of organic acids by probiotic Lactobacilli can be used to reduce pathogen load in poultry. PLoS ONE 7 (9). Article ID e43928.

Ogunbanwo ST, Sanni AI, Onilude AA. 2003. Characterization of bacteriocin produced by Lactobacillus plantarum $\mathrm{F} 1$ and Lactobacillus brevis OG1. Afr J Biotechnol 2(8): 219-227.

Pato U, Johan VS, Khairunnisa F, Hasibuan RDH. 2017. Antibiotic resistance and antibacterial activity of dadih originated Lactobacillus casei subsp. casei R-68 against foodborne pathogens. Asian J Microbiol Biotech Env Sci 19 (3): 577-587.

Pinto AL, Fernandes M, Pinto C, Albano H, Castilho F, Teixeira P, Gibbs PA. 2009. Characterization of anti-listeria bacteriocins isolated from shellfish: Potential antimicrobials to control non-fermented seafood. Intl J Food Microbiol 129: 50-58.

Pucci MJ, Vedamuthu ER, Kunka BS, Vandenbergh PA. 1988. Inhibition of Listeria monocytogenes by using bacteriocin PA-1 produced by Pediococcus acidilactici PAC 1.0. Appl Environ Microbiol 54: 23492353.

Rajaram G, Manivasagan P, Thilagavathi B, Saravanakumar A. 2010. Purification and characterization of a bacteriocin produced by Lactobacillus lactis isolated from marine environment. Adv J Food Sci Technol 2 (2): 138-144.

Ross RP, Morgan S, Hill C. 2002. Preservation and fermentation: past, present and future. Intl J Food Microbiol 79: 3-16.

Saeed M, Khan WA, Shabbir MA, Khan MI, Randhawa MA, Yasmin I 2014. Bacteriocins as a natural antimicrobial agent in food preservation: A review. Pak J Food Sci 24 (4): 244-255.
Sakaridis I, Soultos N, Batzios C, Ambrosiadis I, Koidis P. 2014. Lactic acid bacteria isolated from chicken carcasses with inhibitory activity against Salmonella spp. and Listeria monocytogenes. Czech J Food Sci 32 (1): 61-68.

Sankar NR, Priyanka VD, Reddy PS, Rajanikanth P, Kumar VK, Indira M. 2012. Purification and characterization of bacteriocin produced by Lactobacillus plantarum isolated from cow milk. Intl J Microbiol Res 3 (2): 133-137.

Saranya S, Hemashenpagam N. 2013. Purification and characterization of bacteriocin produced by different Lactobacillus species isolated from fermented foods. Intl J Microbiol Res 5 (1): 341-348.

Shokryazdan P, Sieo CC, Kalavathy R, Liang JB, Alitheen NB, Jahromi MF, Ho YW. 2014. Probiotic potential of Lactobacillus strains with antimicrobial activity against some human pathogenic strains. Bio Med Res Intern Article ID 927268: 1-16.

Stiles ME. 1996. Biopreservation by lactic acid bacteria. Ant Van Leeuwenhoek 70: 331-345.

Syukur S, Fachrial E, Jamsari. 2014. Isolation, antimicrobial activity and protein bacteriocin characterization of lactic acid bacteria isolated from dadih in Solok, West Sumatera, Indonesia. Res J Pharm Biol Chem Sci 5 (6): 1096-1104.

Vătuiu DSE, Popa ME. 2015. Lactic acid bacteria inhibitory activity on the pathogens Salmonella and Listeria monocytogenes. Sci Bul Series F Biotechnol 19: 337-342.

Zacharof MP, Lovitt RW. 2012. Bacteriocins produced by lactic acid bacteria. A Review Article. APCBEE Procedia 2: 50-56.

Zhou F, Zhao H, Bai F, Dziugan P, Liu Y, Zhang B. 2014. Purification and characterisation of the bacteriocin produced by Lactobacillus plantarum, isolated from Chinese pickle. Czech J Food Sci 32 (5): 430-436. 